\title{
KEWENANGAN PENUNTUTAN KOMISI PEMBERANTASAN KORUPSI (KPK) PADA KASUS TINDAK PIDANA PENCUCIAN UANG
}

\author{
Oleh: Rony Saputra \\ Advokat dan Mahasiswa Program Doktor Ilmu Hukum Universitas Andalas \\ Alamat Kantor JI. Ikhlas XII No. 16, Andalas Padang \\ Email: ronirajobatuah@gmail.com
}

\begin{abstract}
Abstrak
Sistem peradilan pidana dalam upaya pemberantasan tindak pidana pencucian uang (TPPU) yang dilakukan oleh penegak hukum, seperti kepolisian dan kejaksaan tentu tidak masalah karena mereka memang diberikan mandat oleh undang-undang. Namun, bagaimana dengan KPK? UU No. 30 Tahun 2002 tentang Komisi Pemberantasan Korupsi (UU KPK) tidak memberikan penjelasan. Kewenangan KPK terbatas hanya terkait dengan tindak pidana korupsi. Penelitian ini merupakan penelitian hukum normatif atau penelitian hukum doktrinal dengan menfokuskan dari aspek inventarisasi hukum positif. Hasil penelitian ini diketahui bahwa kewenangan melakukan penuntutan pada perkara TPPU yang tindak pidana asalnya adalah tindak pidana korupsi menurut UU No. 8 Tahun 2010 (UU TPPU) dapat dilakukan oleh jaksa penuntut umum dari kejaksaan dan jaksa penuntut umum dari KPK apabila tindak pidana asalnya tindak pidana korupsi. Ketentuan Pasal 76 Ayat (1) UU TPPU harus dimaknai bahwa penuntut umum sebagai satu kesatuan, sehingga apakah penuntut umum yang bertugas di Kejaksaan Agung RI atau yang bertugas di KPK adalah sama. Dengan demikian, penuntut umum KPK berwenang melakukan penuntutan pada kasus TPPU yang tindak pidana asalnya adalah tindak pidana korupsi. Untuk menghentikan perdebatan kewenangan KPK dalam melakukan penuntutan perkara TPPU sebagaimana diatur oleh UU No. 8 Tahun 2010 tentang TPPU maka perlu merevisi ketentuan Penjelasan Pasal 76 dengan menyebutkan bahwa penuntut umum di KPK mempunyai kewenangan melakukan penuntutan terhadap tindak pidana pencucian uang jika tindak pidana asalnya adalah tindak pidana korupsi yang ditangani oleh KPK.
\end{abstract}

\begin{abstract}
The criminal justice system in efforts to combat money laundering ( $A M L$ ) conducted by law enforcement, such as police and prosecutors is certainly not a problem because they are mandated by law. However, what the Commission? UU no. 30 of 2002 on the Corruption Eradication Commission (KPK Law) did not give an explanation. KPK's authority is limited only related to corruption. This research is a normative legal or doctrinal legal research by focusing on the positive aspects of the legal inventory. The results of this research note that the authority to prosecute in cases of AML that are underlying predicate offenses of corruption, according to Law No. 8 of 2010 (AML Law) can be carried out by the public prosecutor of the prosecutor and the prosecutor of the Commission if the underlying predicate offenses of corruption. The provisions of Article 76 Paragraph (1) Money Laundering Law should be interpreted that the public prosecutor as a whole, so that if the public prosecutor who served in
\end{abstract}


the Attorney General's office or serving in the Commission are the same. Accordingly, the Commission authorized public prosecutor to prosecute in cases of $A M L$ that is the origin of criminal acts of corruption. To stop the debate authority of the Commission in prosecuting cases of AML as stipulated by Law No. 8 of 2010 on money laundering it is necessary to revise the terms of explanation of Article 76 by stating that the public prosecutor at the Commission has the authority to prosecute money laundering if the underlying predicate offenses of corruption are handled by the KPK.

\section{Kata kunci: KPK, TPPU, Penuntutan}

\section{Pendahuluan}

Money laundering atau Tindak Pidana Pencucian Uang (TPPU) merupakan transnational organized crime, dalam pemberantasannya seringkali berkaitan dengan yurisdiksi Negara lain sehingga memerlukan kerja sama internasional. Untuk memberantas money laundering, sejak bulan Juni 2001 Indonesia bersama sejumlah negara lain yang dinilai kurang kooperatif dimasukkan ke dalam daftar Non Cooperative Countries and Territories ${ }^{1}$ oleh Financial Action Task Force on Money Laundering (FATF) suatu gugus tugas yang beranggotakan 31 negara dan 2 organisasi regional. ${ }^{2}$ Kebijakan yang diatur adalah bidang regulasi, keuangan dan penegakan hukum dan dituangkan di dalam $40+9$ rekomendasi FATF. Lembaga FATF kemudian menuntut negaranegara untuk dapat bergabung dalam angka memberantas tindak pidana pencucian uang. Di dalam tuntutannya disebutkan: ${ }^{3}$
"1. Bahwa suatu negara harus memiliki undang-undang yang menetapkan pencucian uang sebagai tindak pidana.

2. Penyedia jasa keuangan (PJK) harus dapat mengidentifikasi dan melaporkan transaksi keuangan yang mencurigakan.

3. Setiap negara memiliki badan intelijen keuangan (financial intelligence unit)".

Indonesia hingga tahun 2001 belum memenuhi tuntutan tersebut, maka dari itu Indonesia masuk ke dalam daftar hitam Non Cooperative Countries And Territories (NCCTS List) yang dikeluarkan oleh FATF karena dianggap sebagai negara yang rawan akan pencucian uang. Walaupun Indonesia tidak pernah menjadi anggota FATF, namun Indonesia tetap dinilai oleh FATF.

TPPU merupakan kejahatan yang dapat merusak sendi-sendi kehidupan ber-

${ }^{1}$ FATF, Press Release 3 Oktober 2003, negara yang masuk ke daftar NCCTS adalah Cook Islands, Mesir, Guatemala, Myanmar, Nauru, Nigeria, Filipina dan Indonesia.

${ }^{2}$ FATF didirikan pada tahun 1989 oleh negara maju yang tergabung ke dalam G7 dan sekarang anggota FATF adalah: Amerika Serikat, Argentina, Australia, Austria, Belgia, Brazil, Canada, Denmark, European Commission, Finlandia, Perancis, Jerman, Yunani, Gulf Cooperation Council, Hongkong (Cina), Islandia, Irlandia, Italy, jepang, Luxembourg, Mexico, Kongdom of Netherlands, New Zealand, Norwegia, Portugal, Russian Federation, Singapura, South Africa, Spanyol, Swedia, Swiss, Turky dan Inggris.

${ }^{3}$ Sabatini H, Implementasi Undang-Undang Tindak Pidana Pencucian Uang (TPPU) di Indonesia (Suatu Gambaran Tentang Pengetahuan dan Aplikasi Aparat Penyidik Penuntut Umum dan PPATK), Jurnal Kriminologi Indonesia, Volume 6, Nomor III, Desember 2010, hlm. 218. 
masyarakat, berbangsa dan bernegara. Hal ini tidak terlepas dari dampak negatif TPPU, antara lain dapat meningkatkan motivasi seseorang atau organisasi kejahatan mengembangkan kejahatannya yang pada gilirannya dapat pula menciptakan kemiskinan dan kebodohan, merusak struktur keuangan dan perekonomian serta terganggunya stabilitas pemerintahan. ${ }^{4}$ Terhadap TPPU ini, Departement of Justice Canada menyebutkan sebagai berikut: ${ }^{5}$

"1. Aktivitas pencucian uang memungkinkan para penjual dan pengedar narkoba, para penyelundup dan para penjahat lainnya untuk memperluas kegiatan operasinya. Hal ini akan meningkatkan biaya penegakan hukum untuk memberantasnya dan biaya pengobatan dan perawatan serta pengobatan kesehatan bagi para korban atau para pecandu narkoba;

2. Aktivitas pencucian uang mempunyai potensi untuk merongrong masyarakat keuangan (financial community) sebagai akibat dari besarnya jumlah uang yang terlibat dalam kegiatan tersebut. Potensi untuk melakukan korupsi meningkat bersamaan dengan peredaran jumlah uang haram yang sangat besar tersebut;
3. Pencucian uang dapat mengurangi pendapatan pemerintah dari sektor pajak dan secara tidak langsung merugikan para pembayar pajak yang jujur dan mengurangi kesempatan kerja yang sah".

TPPU biasanya terjadi dalam tindak pidana khusus, seperti korupsi illegal logging dan narkoba yang pada dasarnya bermotif ekonomi. Tanpa ada kepentingan ekonomi, tindak pidana tersebut tidak akan terjadi. Oleh karena itu, menjadi hal yang penting dalam konteks memupus motivasi seseorang melakukan tindak pidana melalui pendekatan pelacakan, pembekuan, penyitaan dan perampasan aset hasil tindak pidana. Seseorang ataupun kejahatan terorganisir ${ }^{6}$ dengan sendirinya akan menjadi enggan atau tidak memiliki motivasi untuk melakukan suatu perbuatan pidana apabila hasil perbuatan pidana tersebut dikejar dan dirampas untuk Negara. Pendekatan inilah yang sering disebut dengan "strategi pencegahan dan pemberantasan pencucian uang" (anti-money laundering strategy). ${ }^{7}$

Pentingnya membangun rezim anti pencucian uang guna membantu menciptakan stabilitas sistem keuangan karena lembaga keuangan dapat terhindar dari berbagai risiko,

${ }^{4}$ Naskah Akademik Rancangan Undang-Undang tentang Pencegahan dan Pemberantasan Tindak Pidana Pencucian Uang, Jakarta, 2006, hlm. 13.

${ }^{5}$ Department of Justice Canada, Solicitor General Canada, Electronic Money laundering: An Environmental Scan, October 1998, hlm. 4.

${ }^{6}$ Kejahatan terorganisir (organized crime) adalah "any group of individuals whose primary activity involves violating criminal laws to seeks illegal profits and power engaging in racketeering activities and, appropriate, engaging in intricate financial manipulations...". National Advisory Committe on Criminal Justice Standards and Goals, Organized Crime: Report of the Task Force on Organized Crime, (Washington D.C.: Law Enforcement Assistance Administration, 1976), hlm. 213. Lihat juga Donald R Cressey, The Theft of the Nation: The Strcture and Operation of Organized Crime in America, (New York: Harper and Row, 1969), hlm 319.

${ }^{7}$ Sherman T, "International Efforts to Combat Money Laundering: The Role of the Financial Task Force", dalam MacQueen L (ed.), Money Laundering, Edinburgh, 1993, hlm. 12. 
seperti risiko hukum, reputasi, terkonsentrasinya transaksi dan likuiditas, sehingga mampu melaksanakan fungsinya secara efektif. Selain itu, pelaksanaan rezim anti pencucian uang diyakini dapat menurunkan angka kriminalitas, karena pelaku tindak pidana tidak lagi memiliki motivasi untuk mengulangi perbuatannya dan hasil perampasan tindak pidana dapat dimanfaatkan sebesar-besarnya untuk kemakmuran rakyat. Oleh karena itu, pendekatan rezim anti pencucian uang yang dilaksanakan secara efektif bukanlah suatu hal yang mustahil dilakukan.

Sebaliknya, kegagalan dalam mencegah dan memberantas pencucian uang akan berdampak sangat buruk pada sektor keuangan dan penegakan hukum. Melalui aktifitas pencucian uang, para pelaku kejahatan dapat menyembunyikan asal-usul uang atau harta kekayaan $^{8}$ dari hasil kejahatan dengan maksud agar dapat menikmati dan menggunakan hasil kejahatan tersebut secara bebas karena uang tersebut seolah-olah berasal dari suatu kegiatan yang sah.

Dalam perkembangannya, modus pencucian uang semakin kompleks dan canggih, bahkan secara universal telah digolongkan sebagai tindak pidana yang biasa disebut kejahatan "kerah-putih" (white collar crime) dan juga merupakan kejahatan lintas batas negara (transnational crime). ${ }^{9}$ Semakin canggihnya kejahatan pencucian uang, akhirnya mendorong rezim anti pencucian uang untuk merevisi Undang-Undang (UU) No. 15 Tahun 2002 dengan UU No. 25 Tahun 2003. Semakin dicegah maka semakin kompleks tindakan kejahatan yang terjadi. Tipologi atau modusmodus TPPU terus berkembang dan cara-cara yang digunakan semakin kompleks dengan melibatkan berbagai lembaga keuangan dan lembaga lainnya yang terkait dengan keuangan.

Banyak pihak yang sependapat bahwa UU Pencegahan dan Pemberantasan TPPU lebih efektif untuk memulihkan keuangan Negara dalam hal pengembalian aset (asset recovery), jika dibandingkan dengan UU Pemberantasan Tindak Pidana Korupsi. Alasannya karena UU TPPU menggunakan paradigma baru dalam penanganan tindak pidana, yaitu dengan pendekatan follow the money (menelusuri aliran uang) untuk mendeteksi TPPU dan tindak pidana lainnya. Selain itu, UU TPPU juga mampu menjerat aktor mafia peradilan.

Sistem peradilan pidana dalam upaya pemberantasan TPPU yang dilakukan oleh penegak hukum, seperti Kepolisian dan Kejaksaan untuk melaksanakan UU TPPU tentu tidak masalah karena mereka memang

${ }^{8}$ Menurut Sutan Remy Sjahdeini, istilah "harta kekayaan" yang dipergunakan dalam UU TPPU adalah terjemahan dari istilah "property" yang dipakai dalam berbagai undang-undang tentang money laundering diberbagai negara. Sekalipun undang-undang dan tindak pidananya disebut money laundering ("pencucian uang"), namun objeknya tidak terbatas hanya pada uang saja. Sutan Remy Sjahdeini, Seluk-Beluk Tindak Pidana Pencucian Uang dan Pembiayaan Terorisme, (Jakarta: PT Pustaka Utama Grafiti, 2004), hlm. 167168.

9Karakteristik "kejahatan kerah putih" antara lain: (1) tidak kasat mata (low visibility); (2) sangat kompleks (complexity); (3) ketidakjelasan pertanggungjawaban pidana (diffusion of responsibility); (4) ketidakjelasan korban (diffusion of victims); (5) aturan hukum yang samar atau tidak jelas (ambiguous criminal law); dan (6) sulit dideteksi dan dituntut (weak detection and prosecution). Lihat Harkristuti Harkrisnowo, "Kriminalisasi Pencucian Uang (Money Laundering)", makalah disampaikan pada Video Conference Nasional yang diselenggarakan oleh PPATK, BI, UI, UGM, USU, UNDIP, UNAIR, dan ELIPS di Jakarta, tanggal 29 MeiOktober 2004, hlm. 2-4. 
diberikan mandat oleh UU tersebut. Namun, bagaimana dengan KPK? Dalam Pasal 6 huruf C UU No. 30 Tahun 2002 tentang Komisi Pemberantasan Korupsi (UU KPK) menyatakan secara tegas dan jelas bahwa KPK mempunyai tugas melakukan penyelidikan, penyidikan dan penuntutan terhadap tindak pidana korupsi. Pasal 6 tersebut tidak memberikan penjelasan sehingga kewenangan KPK dalam penyelidikan, penyidikan dan penuntutan terbatas hanya terkait dengan tindak pidana korupsi.

KPK dalam penanganan beberapa kasus korupsi pernah menjerat pelaku menggunakan UU TPPU, tetapi tidak sedikit yang mengkritik dan memberikan apresiasi. Kritikan ditujukan pada kewenangan penyidikan dan penuntutan KPK terhadap TPPU. Pada perkara No. 39/ Pid.Sus/TPK/2013/PN.Jkt.Pst dengan terdakwa Ahmad Fathanah, majelis hakim berbeda pendapat (dessenting opinion), ${ }^{10}$ tentang kewenangan KPK dalam menyidik TPPU. Namun, pengusutan hanya terkait dengan kekayaan yang diketahui atau patut diduga berasal dari tindak pidana korupsi. Tetapi, yang berwenang menuntut TPPU adalah jaksa dari Kejaksaan Tinggi atau Kejaksaan Agung, sedangkan jaksa KPK tidak memiliki kewenangan, karena itu surat dakwaan sepanjang mengenai pencucian uang harus dinyatakan tidak dapat diterima. ${ }^{11}$

Terhadap kasus Anas Urbaningrum juga terjadi perbedaan pendapat hakim dalam menilai kewenangan KPK, karena secara eksplisit UU No. 8 Tahun 2010 tidak mencantumkan kewenangan KPK menuntut TPPU, sehingga tidak ada landasan yuridis formal bagi KPK dalam menuntut TPPU. ${ }^{12}$

Pakar hukum pidana Mudzakir dari Universitas Islam Indonesia (UII) berpendapat KPK tidak bewenang untuk menuntut TPPU, ${ }^{13}$ karena dalam UU No. 8 Tahun 2010 tentang TPPU tidak memberikan kewenangan pada KPK, UU TPPU hanya memberikan lisensi pada KPK untuk melakukan penyidikan sesuai dengan Penjelasan Pasal 74.14 Romli Atmasasmita ${ }^{15}$ juga berpendapat sama, karena penuntut KPK tidak berkoordinasi dan berkonsultasi kepada Jaksa Agung. Romli menegaskan tidak ada hubungan struktural dan hierarkis antara jaksa KPK dan Jaksa Agung. Alasan lainnya sebagaimana dikatakan Yunus Husein tidak terdapat ketentuan eksplisit yang menyatakan KPK berwenang menuntut TPPU seperti ketentuan Pasal 71 ayat (2) b, Pasal 72 Ayat (5) c UU TPPU Tahun 2010 yang hanya memberi mandat pada kejaksaan.

\footnotetext{
${ }^{10}$ Hakim tersebut adalah Joko Subagyo dan I Made Hendra.

${ }^{11} \mathrm{http}$ ://nasional.kompas.com/read/2013/11/04/2101274/Vonis.Fathanah.2kim.Beda.Pendapat diakses pada tanggal 23 Maret 2015 jam $12.00 \mathrm{Wib}$.

${ }^{12} \mathrm{http}: / / w w w . g l o b a l i n d o . c o / 2014 / 09 / 24 /$ beda-pendapat-vonis-anas-dua-hakim-sebut-kpk-tak-berwenangtuntut-tppu/ diakses pada tanggal 23 Maret 2015 jam 12.05 Wib.

${ }^{13} \mathrm{http}: / /$ www.republika.co.id/berita/nasional/hukum/13/11/21/mwm5td-pakar-hukum-kpk-tak-berwenangtuntut-tppu diakses pada tanggal 23 Maret 2015 jam 11.35 Wib.

${ }^{14}$ Penjelasan Pasal 74 UU No. 8 Tahun 2010 "Yang dimaksud dengan "penyidik tindak pidana asal" adalah pejabat dari instansi yang oleh undang-undang diberi kewenangan untuk melakukan penyidikan, yaitu Kepolisian Negara Republik Indonesia, Kejaksaan, Komisi Pemberantasan Korupsi (KPK), Badan Narkotika Nasional (BNN), serta Direktorat Jenderal Pajak dan Direktorat Jenderal Bea dan Cukai Kementerian Keuangan Republik Indonesia. Penyidik tindak pidana asal dapat melakukan penyidikan TPPU apabila menemukan bukti permulaan yang cukup terjadinya tindak pidana pencucian uang saat melakukan penyidikan tindak pidana asal sesuai kewenangannya."
}

${ }^{15}$ Romli Atmasasmita, "KPK Tidak Berwenang Menuntut TPPU”, Koran Sindo, 17 Januari 2014. 
Walau terjadi perbedaan pendapat, namun KPK tetap menggunakan UU TPPU dalam perkara korupsi, seperti perkara Nazaruddin, Wa Ode Nurhayati, Lutfhi Hasan Ishaaq, Irjenpol Djoko Susilo, Rubiandini, Anas Urbaningrum dan Akil Mochtar. Oleh karena itu, kewenangan KPK menuntut TPPU menarik untuk dikaji dan dikritisi karena perdebatan terkait dengan kewenangan itu masih terbuka. Dalam penelitian ini akan dibahas mengenai politik hukum UU No. 8 Tahun 2010 tentang TPPU, kewenangan penuntutan pada TPPU menurut UU No. 8 Tahun 2010 dan kewenangan KPK dalam melakukan penuntutan terhadap TPPU.

\section{Metode Penelitian}

Penelitian ini merupakan penelitian hukum normatif atau penelitian hukum doktrinal dengan menfokuskan dari aspek inventarisasi hukum positif. Inventarisasi hukum positif merupakan kegiatan pendahuluan yang bersifat mendasar untuk melakukan penelitian hukum dari tipe-tipe yang lain. Melalui jenis penelitian ini dilakukan melalui proses identifikasi yang kritis-analitis dan selanjutnya melalui proses klasifikasi yang logis-sistematis. Jenis penelitian ini ini tidak berdiri sendiri, tetapi merupakan salah satu tahap dari rangkaian proses suatu penelitian yang menyeluruh. Sebagai penelitian hukum normatif maka sumber data yang dipergunakan adalah data sekunder, terdiri dari bahan hukum primer, sekunder dan tersier. Analisis data dalam penelitian ini dilakukan dengan suatu tahapan ilmiah dilakukan dengan cara kualitatif, yakni dibandingkan atau diterapkan ke dalam peraturan perundang-undangan yang berlaku, pendapat para sarjana (doktrin), serta teoriteori hukum lainnya. Akhir dari pembahasan penelitian ini akan ditarik kesimpulan secara deduktif, yakni penarikan kesimpulan yang diawali oleh hal-hal yang bersifat umum kepada hal-hal yang bersifat khusus.

\section{Pembahasan}

\section{Politik Hukum Undang-Undang Nomor 8 Tahun 2010 tentang Pencegahan dan Pemberantasan Tindak Pidana Pencucian Uang}

Tindak pidana pencucian uang (money laundering) sebagai salah satu enis kejahatan kerah putih (white collar crime) sebenarnya sudah dikenal sejak tahun 1867. Pada saat itu, seorang perompak di laut, Henry Every, dalam perompakannya terakhir merompak kapal Portugis berupa berlian senilai $£ 325.000$ poundsterling (setara Rp5.671.250.000). Harta rampokan ersebut kemudian dibagi bersama anak buahnya, dan bagian Henry Every ditanamkan pada transaksi perdagangan berlian dimana ternyata perusahaan berlian tersebut juga merupakan perusahaan pencucian uang milik perompak lain di darat. Namun, istilah money laundering baru muncul ketika Al Capone, salah satu mafia besar di Amerika Serikat, pada tahun 1920-an, memulai bisnis Laundromats (tempat cuci otomatis). Bisnis ini dipilih karena menggunakan uang tunai yang mempercepat proses pencucian uang agar uang yang mereka peroleh dari hasil pemerasan, pelacuran, perjudian, dan penyelundupan minuman keras terlihat sebagai uang yang halal. Walau demikian, Al Capone tidak dituntut dan dihukum dengan pidana penjara atas kejahatan tersebut, akan tetapi lebih karena telah melakukan penggelapan pajak. Selain Al Capone, terdapat juga Meyer Lansky, mafia yang menghasilkan uang dari kegiatan perjudian dan menutupi bisnis ilegalnya itu dengan mendirikan bisnis hotel, lapangan golf dan perusahaan pengemasan daging. Uang hasil bisnis illegal ini dikirimkan ke beberapa bank-bank di Swiss yang sangat 
mengutamakan kerahasian nasabah, untuk didepositokan. Deposito ini kemudian diagunkan untuk mendapatkan pinjaman yang dipergunakan untuk membangun bisnis legalnya. Berbeda dengan Al Capone, Meyer Lansky justru terbebas dari tuntutan melakukan penggelapan pajak, tindak pidana termasuk tindak pidana pencucian uang yang dilakukannya. ${ }^{16}$

Istilah money laundering berasal dari Amerika Serikat, istilah ini mempunyai sejarah panjang dimulai dari tahun 1930 yang pada waktu itu para pelaku kejahatan terorganisir oleh mafia. ${ }^{17}$ Kelompok kriminal ini melakukan diversifikasi usaha atas hasil kejahatannya dengan cara mengambil alih aktivitas bisnis legal tertentu dengan hasil keuntungan keuangan yang sangat tinggi. ${ }^{18}$

Money laundering secara populer dapat dijelaskan sebagai aktivitas memindahkan, menggunakan atau melakukan perbuatan lainnya atas hasil dari tindak pidana yang kerap dilakukan oleh organized crime maupun individu yang melakukan tindakan korupsi, perdagangan narkotik dan tindak pidana lainnya dengan tujuan menyembunyikan atau mengaburkan asal-usul uang yang berasal dari hasil tindak pidana tersebut sehingga dapat digunakan seolah-olah sebagai uang yang sah tanpa terdeteksi bahwa uang tersebut berasal dari kegiatan illegal. ${ }^{19}$ Menurut Barda Nawawi
Arief, dapat dikatakan ada 3 (tiga) jenis TPPU, yaitu ${ }^{20}$

"1. Mengubah atau memindahkan property yang berasal dari kejahatan dengan tujuan menyembunyikan asal usul property itu atau untuk membantu seseorang menghindari akibat-akibat dari keterlibatannya dalam melakukan kejahatan.

2. Menyembunyikan keadaan sebenarnya dari property yang berasal dari kejahatan itu (baik sumber/asalusulnya, lokasi, penempatan, pergerakan, penyaluran maupun hak-hak yang berhubungan dengan property itu.

3. Menguasai/menerima, memiliki atau menggunakan property yang diketahuinya berasal dari kejahatan atau dari keikutsertaannya dalam melakukan kejahatan itu".

UU No. 8 Tahun 2010 Pasal 1 point (1) menjelaskan yang dimaksud dengan pencucian uang adalah segala perbuatan yang memenuhi unsur-unsur tindak pidana sesuai dengan ketentuan dalam undang-undang ini. Sementara yang dimaksud dengan TPPU sebagai berikut: "Setiap Orang yang menempatkan, mentransfer, mengalihkan, membelanjakan, membayarkan, menghibahkan, menitipkan, membawa ke luar negeri, mengubah bentuk, menukarkan dengan mata

\footnotetext{
${ }^{16}$ Iwan Kurniawan, Perkembangan Tindak Pidana Pencucian Uang (Money Laundering) dan Dampaknya Terhadap Sektor Ekonomi dan Bisnis, Jurnal IImu Hukum, Volume 3, Nomor 1, 2010, hlm. 4.

${ }^{17}$ Yunus Husein, Tindak Pidana Pencucian Uang (Money Laundering) Dalam Perspektif Hukum Internasional, Jurnal Hukum International (Indonesian Journal of International Law), Volume 1, Nomor 2 , Januari 2014, Faculty of Law University of Indonesia, hIm. 1.

${ }^{18}$ Romli Atmasasmita, Globalisasi dan Kejahatan Bisnis, (Jakarta: Kencana, 2010), hlm. 52.

${ }^{19}$ Yunus Husein, PPATK: Tugas, Wewenang, dan Peranannya Dalam Memberantas Tindak Pidana Pencucuian Uang, Jurnal Hukum Bisnis, Volume 22, Nomor 3, 2003, hlm. 26.

${ }^{20}$ Barda Nawawi Arief, Masalah Penegakan Hukum \& Kebijakan Penanggulangan Kejahatan, (Bandung: Citra Aditya Bakti, 2001), hlm. 212-213.
} 
uang atau surat berharga atau perbuatan lain atas harta kekayaan yang diketahuinya atau patut diduganya merupakan hasil tindak pidana sebagaimana dimaksud dalam Pasal 2 Ayat (1) dengan tujuan menyembunyikan atau menyamarkan asal usul harta kekayaan dipidana karena tindak pidana pencucian uang dengan pidana penjara paling lama 20 (dua puluh) tahun dan denda paling banyak Rp10.000.000.000,00 (sepuluh miliar rupiah).

Money laundering dewasa ini dinyatakan sebagai bentuk kejahatan perbankan yang merugikan perekonomian bangsa. Kejahatan ini menyangkut pelanggaran di bidang ekonomi dengan memanfaatkan jasa perbankan, keterlibatan perbankan dalam kegiatan pencucian uang dapat berupa: ${ }^{21}$

"1. Penyimpanan uang hasil kejahatan dengan nama palsu atau dalam safe deposit box.

2. Penyimpanan uang dalam bentuk deposito/tabungan/giro.

3. Penukaran pecahan uang hasil perbuatan illegal.

4. Pengajuan permohonan kredit dengan jaminan uang yang disimpan pada bank yang bersangkutan.

5. Penggunaan fasilitas transfer atau EFT.

6. Pemalsuan dokumen-dokumen L/C yang bekerjasama dengan oknum pejabat bank terkait.

7. Pendirian/pemanfaatan bank gelap".
Kejahatan yang terkait dengan masalah pencucian uang atau money laundering selama ini belum tersentuh oleh kebijakan politik hukum pidana dalam upaya untuk menanggulangi meningkatnya kasus pelanggaran hukum tersebut. Kejahatan ini diangap baru dan sesungguhnya termasuk ke dalam extraordinary crime bahkan serious crime karena mempunyai modus operandi yang berbeda dan berbahaya dari kejahatan konvensional yang dikenal dalam hukum pidana Indonesia. ${ }^{22}$

Hukum pidana sebagai sebuah entitas yang sangat kompleks meliputi kenyataan kemasyarakatan yang majemuk, mempunyai banyak aspek, dimensi dan fase..$^{23}$ Begitu juga fase-fase lahirnya ketentuan pidana tentunya tidak terlepas dari politik hukum pada umumnya, ${ }^{24}$ yakni setiap usaha untuk mewujudkan peraturan yang baik serta sesuai dengan kondisi maupun situasi tertentu. Begitu juga politik hukum pidana berusaha untuk membuat peraturan perundang-undangan pidana yang merujuk pada kondisi dan situasi yang sesuai dan wajar seperti yang diharapkan dan dimaksudkan oleh masyarakat. ${ }^{25}$

Indonesia pada 17 April 2002 mensahkan UU No. 15 Tahun 2002 tentang TPPU. Namun, oleh FATF undang-undang tersebut diminta untuk direvisi karena tidak sesuai dengan rekomendasi internasional. Materi UU No. 15 Tahun 2002 tersebut dianggap tidak sesuai

${ }^{21}$ Guy Stessens, Money Laundering : A New International Law Enforcement Model, (Cambridge University Press: First Published, 2000), hlm. 9.

${ }^{22}$ Teguh Sulistia dan Aria Zurnetti, Hukum Pidana Horizon Baru Pasca Reformasi, (Jakarta: Raja Grafindo Persada, 2011), hlm. 96.

${ }^{23}$ Imam Syaukani dan A. Ahsin Thohari, Dasar-Dasar Politik Hukum, (Jakarta: PT Raja Grafindo Persada, 2007), hlm. 1.

${ }^{24}$ Bernard Arief Sidharta, Refleksi Tentang Struktur IImu Hukum: Sebuah Penelitian Tentang Fondasi Kefilsafatan dan Filsafat Keilmuan IImu Hukum Sebagai Landasan Pengembangan IImu Hukum Nasional Indonesia, (Bandung: Mandar Maju, 1999), hlm. 116.

${ }^{25}$ Cainur Arrasjid, Hukum Pidana Perbankan, (Jakarta: Sinar Grafika, 2011), hlm. 92. 
dengan pengertian transaksi keuangan mencurigakan. Adapun materi dianggap tidak sesuai tersebut, seperti dianggap kurang luas karena batasan lima ratus juta untuk mendefinisikan "hasil kejahatan", tidak adanya ketentuan "anti tiffing of" yang melarang bank atau pejabat tertentu untuk memberitahukan tentang laporan transaksi keuangan mencurigakan yang sedang disusun atau telah dilaporkan, jangka waktu pelaporan transaksi keuangan mencurigakan yang dianggap terlalu lama, yaitu empat belas hari kerja dan tidak adanya ketentuan bantuan hukum timbal balik (mutual legal assistance). ${ }^{26}$ Sehingga pada akhirnya UU No. 15 Tahun 2002 dirubah menjadi UU No. 25 Tahun 2003 tentang TPPU.

Dari sisi eksternal, faktor perlunya dilakukan pembaharuan hukum mengenai pencegahan dan pemberantasan TPPU, yaitu dikeluarkannya revisi rekomendasi Financial Action Task Force on Money Laundering (FATF) sebagai "standard setter" dalam pencegahan dan pemberantasan pencucian uang yang harus diadopsi oleh semua negara, dan adanya perkembangan international best practice. Salah satu dari rekomendasi tersebut memperluas lingkup dari pihak pelapor (reporting parties) yang wajib menyampaikan laporan transaksi keuangan mencurigakan (LTKM/STR) kepada lembaga yang berfungsi sebagai Financial Intelligence Unit (FIU) seperti PPATK. Bahkan rekomendasi FATF tersebut tegas menyatakan agar pengacara, notaris atau profesi hukum lainnya dan akuntan serta penyedia barang dan jasa diminta untuk ikut melaporkan LTKM/STR. Kondisi di atas mendorong direvisinya UU No. 25 Tahun 2003 menjadi UU No. 8 Tahun 2010 tentang Pencegahan dan Pemberantasan TPPU pada tanggal 22 Oktober 2010.

UU No. 8 Tahun 2010 merupakan perwujudan politik hukum pidana sangat berdayaguna dalam menanggulangi prilaku "white collar criminal" atau "penjahat kerah putih" dalam menjalankan aksi kejahatannya terutama saat Indonesia masih mengalami krisis ekonomi. Kehadiran undang-undang ini sangat mendukung penegakan hukum dalam memelihara dan menjaga stabilitas moneter dan keuangan bangsa dalam hukum pidana. ${ }^{27}$

Pencegahan dan pemberantasan TPPU memerlukan landasan hukum yang kuat untuk menjamin kepastian hukum, efektifitas penegakan hukum, serta penelusuran dan pengembalian harta kekayaan hasil tindak pidana. ${ }^{28}$ Pada umumnya pelaku tindak pidana berusaha menyembunyikan atau menyamarkan asal usul harta kekayaan yang merupakan hasil dari tindak pidana dengan berbagai cara agar sehingga dengan leluasa memanfaatkan harta kekayaan tersebut baik untuk kegiatan yang sah maupun tidak sah. Karena itu, TPPU tidak hanya mengancam stabilitas dan integritas sistem perekonomian dan sistem keuangan, tetapi juga dapat membahayakan sendi-sendi kehidupan bermasyarakat, berbangsa, dan bernegara berdasarkan Pancasila dan UndangUndang Dasar Negara Republik Indonesia Tahun 1945.

Dalam konsep anti pencucian uang, pelaku dan hasil tindak pidana dapat diketahui melalui penelusuran untuk selanjutnya hasil

\footnotetext{
${ }^{26}$ Lihat surat Presiden FATF kepada Menteri Kehakiman dengan tembusan kepada Kepala PPATK a.I. tanggal 8 Juli 2003.

${ }^{27}$ Teguh Sulistia dan Aria Zurnetti, Hukum Pidana... Op.Cit., hlm. 95.

${ }^{28}$ Toetik Rahayuningsih, Analisis Peran PPATK Sebagai Salah Satu Lembaga Dalam Menanggulangi Money Laundering di Indonesia, Jurnal Yuridika, Volume 28, Nomor 3, September - Desember 2013, hlm. 318.
} 
tindak pidana tersebut dirampas untuk negara atau dikembalikan kepada yang berhak. Apabila harta kekayaan hasil tindak pidana yang dikuasai oleh pelaku atau organisasi kejahatan dapat disita atau dirampas, dengan sendirinya dapat menurunkan tingkat kriminalitas. Oleh karena itu, TPPU merupakan perwujudan politik hukum pidana dalam menanggulangi prilaku "white collar criminal" atau "penjahat kerah putih".

\section{Kewenangan Penuntutan Pada Tindak Pidana Pencucian Uang Menurut Undang- Undang No. 8 Tahun 2010}

Dalam hukum acara Indonesia kewenangan penuntutan diatur dalam Pasal 1 angka 6 UU No. 8 Tahun 1981 tentang Kitab Undang-Undang Hukum Acara Pidana (KUHAP). Pasal tersebut menegaskan "Jaksa adalah pejabat yang diberi wewenang oleh undang-undang ini untuk bertindak sebagai penuntut umum serta melaksanakan putusan pengadilan yang telah memperoleh kekuatan hukum tetap", sedangkan yang dapat bertindak sebagai penuntut umum adalah jaksa yang diberi wewenang oleh undang-undang ini untuk melakukan penuntutan dan melaksanakan penetapan hakim.

Selanjutnya perihal penuntutan ini diatur lebih lanjut dalam UU No. 16 Tahun 2004 tentang Kejaksaan Republik Indonesia. Pasal 2 UU No. 16 Tahun 2004 menegaskan Kejaksaan adalah lembaga pemerintah yang melaksanakan kekuasaan negara di bidang penuntutan serta kewenangan lain berdasarkan undang-undang serta merupakan satu kesatuan yang tidak terpisahkan.

Menurut UU No. 16 Tahun 2004, Kejaksaan memiliki tugas dan kewenangan meliputi bidang pidana, perdata dan ketenteraman umum. Dalam bidang pidana, Kejaksaan memiliki kewenangan: 1).melakukan penuntutan; 2). melaksanakan penetapan hakim dan putusan pengadilan yang telah memperoleh kekuatan hukum tetap; 3).melakukan pengawasan terhadap pelaksanaan putusan pidana bersyarat, putusan pidana pengawasan, dan keputusan lepas bersyarat, melakukan penyelidikan terhadap tindak pidana tertentu berdasarkan undang-undang, dan;4). melengkapi berkas perkara tertentu dan untuk itu dapat melakukan pemeriksaaan tambahan sebelum dilimpahkan ke pengadilan yang dalam pelaksanaannya dikoordinasikan dengan penyidik.

Secara hukum penuntutan diartikan sebagai tindakan penuntut umum untuk melimpahkan perkara pidana ke pengadilan negeri yang berwenang dalam hal dan menurut cara yang diatur dalam undang-undang ini dengan permintaan supaya diperiksa dan diputus oleh hakim di sidang pengadilan. ${ }^{29}$ Sementara penuntut umum bukanlah semua jaksa yang ada di lembaga kejaksaan, tetapi jaksa yang diberi wewenang oleh undangundang ini untuk melakukan penuntutan dan melaksanakan penetapan hakim. ${ }^{30}$

Jika mengacu pada ketentuan di atas dan berdasarkan asas dominus litis maka penetapan dan pengendalian kebijakan penuntutan hanya berada di satu tangan, yaitu institusi kejaksaan yang kemudian dilakukan oleh jaksa yang diangkat dan diberhentikan oleh Kejaksaan Agung. Selanjutnya, untuk melihat lebih jauh makna yang terkandung dalam Pasal 2 Ayat (3) UU No. 16 Tahun 2004 menyatakan bahwa kejaksaan sebagaimana dimaksud pada Ayat (1) adalah satu dan tidak terpisahkan.

${ }^{29}$ Lebih lanjut lihat ketentuan Pasal 1 angka 7 KUHAP.

${ }^{30}$ Lebih lanjut lihat ketentuan Pasal 1 angka 2 UU No. 16 Tahun 2004. 
Ketentuan ini setidaknya memberikan gambaran bahwa kejaksaan itu hanya satu dan apabila ia (jaksa penuntut umum) ditugaskan di lembaga lain maka ia tetap dianggap kejaksaan, karena yang bisa mengangkat dan memberhentikan jaksa hanyalah Kejaksaan Agung.

Lalu bagaimana dengan kewenangan penuntutan terhadap TPPU? Secara umum TPPU dapat diartikan sebagai aktifitas memindahkan, menggunakan atau melakukan perbuatan lainnya atas hasil dari tindak pidana yang kerap dilakukan oleh organized crime maupun individu yang melakukan tindakan korupsi, perdagangan narkotik dan tindak pidana lainnya dengan tujuan menyembunyikan atau mengaburkan asal-usul uang yang berasal dari hasil tindak pidana tersebut sehingga dapat digunakan seolah-olah sebagai uang yang sah tanpa terdeteksi bahwa uang tersebut berasal dari kegiatan illegal. ${ }^{31}$ UU No. 8 Tahun 2010 mengartikan tindak pidana pencucian uang sebagai upaya menempatkan, mentransfer, mengalihkan, membelanjakan, membayarkan, menghibahkan, menitipkan, membawa ke luar negeri, mengubah bentuk, menukarkan dengan mata uang atau surat berharga atau perbuatan lain atas harta kekayaan yang diketahuinya atau patut diduganya merupakan hasil tindak pidana sebagaimana dimaksud dalam Pasal 2 Ayat $(1)^{32}$ dengan tujuan menyembunyikan atau menyamarkan asal usul harta kekayaan. ${ }^{33}$ Pada bagian ini perlu digaris bawahi adalah “...harta kekayaan yang diketahui atau patut diduganya merupakan hasil tindak pidana...".

Mengenai penuntutan terkait dengan TPPU dapat dilihat dalam Pasal 76, yang berbunyi:

"(1) Penuntut umum wajib menyerahkan berkas perkara TPPU kepada pengadilan negeri paling lama 30 (tiga puluh) hari kerja terhitung sejak tanggal diterimanya berkas perkara yang telah dinyatakan lengkap.

(2) Dalam hal penuntut umum telah menyerahkan berkas perkara kepada pengadilan negeri sebagaimana dimaksud pada Ayat (1), ketua pengadilan negeri wajib membentuk majelis hakim perkara tersebut paling lama 3 (tiga) hari kerja sejak diterimanya berkas perkara tersebut".

UU TPPU tidak menjelaskan siapa yang dapat melakukan penuntutan terkait dengan TPPU. Apakah jaksa penuntut umum dari kejaksaan atau bisa penuntut umum dari di lembaga lain? Beranjak dari doktrin lex specialist maka UU TPPU merupakan aturan khusus dari KUHAP. Artinya, sepanjang tidak diatur oleh UU TPPU maka ketentuan hukum acara terkait dengan TPPU harus merujuk pada ketentuan KUHAP.

Sebagaimana sudah disinggung bahwa lembaga negara yang berwenang melakukan penuntutan adalah jaksa penuntut umum

${ }^{31}$ Yunus Husein, PPATK: Tugas, Wewenang...Op.Cit., hlm. 26.

${ }^{32}$ Pasal 2 Ayat (1) UU TPPU "Hasil tindak pidana adalah Harta Kekayaan yang diperoleh dari tindak pidana: a. korupsi; b. penyuapan; c. narkotika; d. psikotropika; e. penyelundupan tenaga kerja; f. penyelundupan migran; g. di bidang perbankan; h. di bidang pasar modal; i. di bidang perasuransian; j. kepabeanan; k. cukai; I. perdagangan orang; $m$. perdagangan senjata gelap; $n$. terorisme; o. penculikan; p. pencurian; q. penggelapan; r. penipuan; s. pemalsuan uang; t. perjudian; u. prostitusi; v. di bidang perpajakan; w. di bidang kehutanan; $x$. di bidang lingkungan hidup; y. di bidang kelautan dan perikanan; atau z. tindak pidana lain yang diancam dengan pidana penjara 4 (empat) tahun atau lebih".

${ }^{33}$ Lebih lanjut lihat ketentuan Pasal 3 UU No. 8 Tahun 2010. 
yang diangkat dan diberhentikan oleh Jaksa Agung, sedangkan penuntut umum yang ada di KPK adalah penuntut umum yang ditugaskan oleh kejaksaan. Selain itu, ada frasa "...harta kekayaan yang diketahui atau patut diduganya merupakan hasil tindak pidana..." salah satunya dari hasil tindak pidana korupsi maka KPK merupakan lembaga yang diberwenang berdasarkan UU No. 30 Tahun 2002 untuk melakukan penyelidikan, penyidikan dan penuntutan terhadap tindak pidana korupsi.

Beberapa kasus TPPU yang ditangani KPK pernah dibarengi dengan tindak pidana asal berupa tindak pidana korupsi, di mana fakta hukum terkait kedua tindak pidana tersebut saling berhubungan dan saling mendukung. Bahkan dengan tipologi yang terstruktur maka penangannya pun harus dilakukan secara terintegritas. Oleh karena itu, sangat penting untuk menjamin bahwa kewenangan penuntutan TPPU yang berasal dari tindak pidana korupsi yang ditangani oleh KPK harus dibarengi dengan kewenangan penuntutan tindak pidana korupsi (sebagai tindak pidana asal). Hal ini sejalan dengan prinsip penanganan perkara yang cepat, sederhana dan biaya ringan serta tercapainya pengembalian keuangan Negara yang optimal dan tidak menimbulkan proses penanganan yang bolak balik untuk menjamin adanya kepastian hukum. ${ }^{34}$ Cara demikian menjadi salah satu jalan untuk mencapai tujuan pembentukan KPK, yaitu dalam upaya mencegah dan memberantas korupsi. Jika suatu perkara yang ditangani KPK dibarengi dengan TPPU, sedangkan penuntutan diserahkan ke Kejaksaan Negeri maka penangannya menjadi tidak efektif dan efisien karena akan menimbulkan beban, biaya besar dan waktu yang lebih lama.

Bila diperhatikan ketentuan Pasal 6 UU No. 8 Tahun 2010 diketahui bahwa pengadilan tindak pidana korupsi berdasarkan Pasal 5 berwenang memeriksa, mengadili, dan memutus perkara, tindak pidana korupsi tindak pidana pencucian uang yang tindak pidana asalnya adalah tindak pidana korupsi, dan/atau tindak pidana yang secara tegas dalam undangundang lain ditentukan sebagai tindak pidana korupsi. Dengan demikian, kewenangan melakukan penuntutan perkara TPPU yang tindak pidana asalnya merupakan tindak pidana korupsi berdasarkan UU No. 8 Tahun 2010 dapat dilakukan oleh jaksa penuntut umum dari kejaksaan dan dapat juga dilakukan oleh jaksa penuntut umum dari KPK sepanjang tindak pidana asalnya adalah tindak pidana korupsi yang ditangani oleh KPK.

\section{Kewenangan Komisi Pemberantasan Korupsi Dalam Melakukan Penuntutan Terhadap Tindak Pidana Pencucian Uang}

Beberapa tahun terakhir, KPK semakin gencar menerapkan pasal pencucian uang dalam perkara korupsi. KPK hampir selalu menerapkan pasal pencucian uang terhadap tersangka korupsi yang kekayaannya jauh melampaui pendapatannya. Beberapa contohnya, seperti Presiden PKS Lutfhi Hasan Ishaaq, mantan Kepala SKK Migas Rudi Rubiandini dan mantan Ketua MK M Akil Mochtar. Hal itu dilakukan karena penerapan pasal pencucian uang terhadap tersangka korupsi akan menimbulkan efek jera sehingga pemberantasan korupsi jadi lebih efektif. ${ }^{35}$

${ }^{34}$ Yahya Harahap, Pembahasan Permasalahan dan Penerapan KUHAP, (Jakarta: Sinar Grafika, 2010), hIm. 49.

${ }^{35}$ Indonesia Legal Rountable, http://www.ilr.or.id/2014/08/penggunaan-pasal-pencucian-uang-naik/ diakses pada tanggal 24 Maret 2015 jam 20.00 Wib 
Sebelum menjawab apakah jaksa penuntut umum pada KPK berwenang melakukan penuntutan TPPU, terlebih dahulu perlu dibahas mengenai kewenangan itu sendiri. Dalam hukum tata negara, kewenangan diartikan sebagai kekuasaan yang sah/ legitimate. Kata kewenangan dalam bahasa Inggris disebut juga dengan authority dan dalam bahasa Belanda disebut dengan bovedegheid. Kekuasaan yang sah karena undang-undang yang memberikan kewenangan tersebut, dengan kata lain tidak ada kewenangan tanpa undang-undang yang mengaturnya. Dalam asas hukum dikenal dengan asas legalitas. Dengan demikian, munculnya kewenangan untuk membatasi agar penyelenggara negara dalam melaksanakan pemerintahan dapat dibatasi kewenangannya agar tidak berlaku sewenang-wenang. Kemudian muncul pula asas dalam hukum administrasi negara "tidak ada kewenangan tanpa pertanggungjawaban". Oleh karena itu, siapapun atau pejabat manapun harus mempertanggungjawabkan setiap tugas dan kewenangannya. Untuk mengetahui lebih lanjut siapa yang mesti bertanggung jawab dapat dikaitkan dengan cara memperoleh wewenang:

"1. Atribusi adalah pemberian kewenangan pemerintahan oleh pembuat undangundang kepada organ pemerintahan tersebut. Artinya kewenangan itu bersifat melekat terhadap pejabat yang dituju atas jabatan yang diembannya. Misalnya berdasarkan Pasal 41 UU No. 27 Tahun 2009 tentang MD3 menegaskan "DPR dapat membentuk undangundang untuk disetujui bersama dengan Presiden".

2. Delegasi adalah pelimpahan kewenangan pemerintahan dari organ pemerintahan yang satu kepada organ pemerintahan lainnya. Atau dengan kata lain terjadi pelimpahan kewenangan. Jadi tanggung jawab/ tanggung gugat berada pada penerima delegasi/delegataris. Misalnya, Pemerintah Pusat memberi delegasi kepada semua Pemda untuk membuat Perda (termasuk membuat besluit/ keputusan) berdasarkan daerahnya masing-masing".

3. Mandat terjadi jika organ pemerintahan mengizinkan kewenangannya dijalankan oleh organ lain atas namanya. Pada mandat tidak terjadi peralihan tanggung jawab, melainkan tanggung jawab tetap melekat pada si pemberi mandat. Misalnya instruksi Gubernur kepada Sekretaris Daerah agar ia bertanda tangan untuk keputusan pencairan anggaran pendidikan. Jadi, di sini jika jika keputusan yang hendak digugat berarti tetap yang digugat/sebagai tergugat adalah Gubernur".

Terkait dengan Penuntutan, di dalam hukum acara Indonesia setidaknya terdapat 3 (tiga) aturan yang mengatur, yaitu KUHAP, Undang-Undang Kejaksaan dan UndangUndang Komisi Pemberantasan Korupsi. Di dalam KUHAP dijelaskan bahwa penuntut umum adalah jaksa yang diberi wewenang oleh undang-undang untuk melakukan penuntutan. ${ }^{36}$ Selanjutnya pada Pasal 2 Ayat (1) UU No. 16 Tahun 2004 tentang Kejaksaan RI menegaskan bahwa kejaksaan adalah lembaga pemerintahan yang melaksanakan kekuasaan negara di bidang penuntutan serta kewenangan lain berdasarkan undang-undang. Pada Pasal 2 Ayat (3) UU Kejaksaan menegaskan bawah kejaksaan sebagaimana

\footnotetext{
${ }^{36}$ Lebih lanjut lihat ketentuan Pasal 1 Butir 13 KUHAP.
} 
dimaksud pada Ayat (1) adalah satu dan tidak dipisahkan.

Terkait dengan KPK sendiri, ia dibentuk sesuai dengan ketentuan Pasal $43^{37}$ UU 31 Tahun 1999 tentang Pemberantasan Tindak Pidana Korupsi sebagaimana telah diubah dengan UU No. 20 Tahun 2001 tentang perubahan atas UU No. 31 Tahun 1999 dengan tugas dan wewenang melakukan pemberantasan tindak pidana korupsi. Jika mengacu pada ketentuan di atas maka kewenangan KPK hanya dalam hal pemberantasan korupsi. Selanjutnya, jika lebih jauh melihat ketentuan Pasal 1 Ayat (1) UU No. 30 Tahun 2002 jo Pasal 4 UU No. 30 Tahun 2002 jo Pasal 6 poin c UU No. 30 Tahun 2002 jo Pasal 38 Ayat (1) dan (2) UU No. 30 Tahun 2002 jo Pasal 39 Ayat (1) UU No. 30 Tahun 2002, dapat dilihat bahwa KPK dibentuk untuk menangani tindak pidana korupsi mulai dari penyelidikan, penyidikan, maupun penuntutan.

Berbicara mengenai penuntutan dalam perkara TPPU maka tidak bisa dilepaskan dari penyidikan. Pasal 74 UU TPPU menyatakan "Penyidikan TPPU dilakukan oleh penyidik tindak pidana asal sesuai dengan ketentuan hukum acara dan ketentuan peraturan perundang-undangan, kecuali ditentukan lain menurut undang-undang ini". Berdasarkan ketentuan di atas maka KPK sebagai penyidik tindak pidana asal, proses pengusutan harta dan kekayaan yang diduga berasal tindak pidana korupsi membutuhkan pengetahuan dan pemahaman yang utuh untuk menyelidiki sumber uang, proses transaksi, pelaku yang terlibat serta dalam menentukan kerugian keuangan Negara dan pelaku sebenarnya maka berdasarkan Pasal 75 UU TPPU tertulis proses penyidikan TPPU dan tindak pidana asal dalam hal ini Tindak Pidana Korupsi dapat digabungkan.

Penggabungan penyidikan antara TPPU dengan tindak pidana korupsi harus sistematis dan sinergi dengan penyidikan dan penuntutan yang dilakukan oleh KPK, karena esensi adalah proses pemeriksaan dan pengusutan harta dan kekayaan dari pelaku kejahatan agar optimal, apabila penyidikan dan penuntutan dalam TPPU tersebut dapat dilakukan KPK secara sistematis maka proses penuntutan TPPU dalam sidang pengadilan lebih berkualitas dan pengusutan harta kekayaan yang akan disita guna mengembalikan kerugian keuangan dan perekonomian Negara dapat dilakukan secara benar dan pasti.

TPPU, dikategorikan sebagai tindak khusus, sehingga penanganannya tidak cukup dilakukan dengan penanganan biasa seperti penanganan kejahatan konvensional pada umumnya. Apabila wewenang KPK pada penanganan TPPU hanya terbatas pada penyidikan yang hanya membuat berkas acara pemeriksaan kemudian diserahkan kepada jaksa penuntut umum maka proses seperti ini justru memperumit dan dapat menimbulkan celah hukum, sedangkan sisi lain TPPU yang

${ }^{37}$ Bunyi Ketentuan Pasal 43: Dalam waktu paling lambat 2 (dua) tahun sejak undang-undang ini mulai berlaku, dibentuk Komisi Pemberantasan Tindak Pidana Korupsi. Komisi sebagaimana dimaksud dalam Ayat (1) mempunyai tugas dan wewenang melakukan koordinasi dan supervisi, termasuk melakukan penyelidikan, penyidikan, dan penuntutan sesuai dengan ketentuan peraturan perundang-undangan yang berlaku. (2) Keanggotaan Komisi sebagaimana dimaksud dalam Ayat (1) terdiri atas unsur Pemerintah dan unsur masyarakat. (3) Ketentuan mengenai pembentukan, susunan organisasi, tata kerja, pertanggungjawaban, tugas dan wewenang, serta keanggotaan Komisi sebagaimana dimaksud dalam Ayat (1) Ayat (2), dan Ayat (3) diatur dengan undang-undang. 
berasal dari tindak pidana korupsi harus segera ditangani guna menentukan pelaku dan jumlah kerugian keuangan Negara. Proses penanganan TPPU yang berasal dari tindak pidana korupsi yang rumit tersebut dapat dilihat dari penjelasan berikut: 38

“1. Penyidik menyerahkan berkas perkara kepada penuntut umum (Pasal 8 , Pasal 14 huruf a dan Pasal 110 Ayat (1) KUHAP);

2. Penuntut umum memberikan perpanjangan penahanan atas permintaan penyidik (Pasal 14 huruf $c$ dan Pasal 24 Ayat (2) KUHAP);

3. Dalam hal penuntut umum berpendapat hasil penyidikan belum lengkap, ia segera mengembalikan kepada penyidik disertai petunjuknya dan penyidik wajib melengkapinya dengan melaksanakan penyidikan tambahan (Pasal 14 huruf $b$ dan Pasal 110 Ayat (2) dan Ayat (3) KUHAP);

4. Dalam hal penyidik mulai melakukan penyidikan/pemeriksaan, memberitahukan hal kepada penuntut umum (Pasal 109 Ayat (1) KUHAP);

5. Dalam hal penyidikan menghentikan penyidikan, pemberitahuan hal itu kepada penuntut umum (Pasal 109 Ayat (2) KUHAP). Sebaliknya, dalam hal penuntut umum menghentikan penuntutan ia memberitahukan turunan surat ketetapan kepada penyidik (Pasal 140 Ayat (2) huruf c KUHAP);

6. Penuntut umum memberitahukan turunan surat pelimpahan perkara, surat dakwaan kepada penyidik (Pasal
143 Ayat (4) KUHAP), demikian pula dalam hal penuntut umum mengubah surat dakwaan ia memberikan turunan perubahan surat dakwaan kepada penyidik (Pasal 144 Ayat (3) KUHAP)".

Jika langkah-langkah di atas harus dilakukan maka proses peradilan dalam TPPU yang tindak pidana asalnya adalah tindak pidana korupsi akan berjalan sangat lama dan tidak efektif. Beranjak dari doktrin lex specialist, UU TPPU khususnya berkaitan dengan ketentuan hukum acara merupakan aturan khusus dari KUHAP yang berlaku saat ini. Artinya, sepanjang tidak ditentukan secara khusus oleh UU TPPU, semua hukum acara pidana terkait dengan perkara TPPU masih merujuk pada ketentuan KUHAP. Pasal 1 angka 7 KUHAP menyebutkan Penuntutan adalah "tindakan penuntut umum untuk melimpahkan perkara pidana ke pengadilan negeri yang berwenang dalam hal dan menurut cara yang diatur dalam undangundang ini dengan permintaan supaya diperiksa dan diputus oleh hakim di sidang pengadilan". Sementara penuntut umum adalah jaksa yang diberi wewenang oleh undang-undang ini untuk melakukan penuntutan dan melaksanakan penetapan hakim.

Berdasarkan hal di atas muncul pemahaman bahwa tugas penuntutan merupakan kewenangan khusus yang dimiliki oleh institusi kejaksaan yang kemudian dilakukan oleh jaksa yang diangkat dan diberhentikan oleh Jaksa Agung. ${ }^{39}$ Tidak hanya itu, sebelum memangku jabatan sebagai jaksa, terlebih dahulu harus disumpah di hadapan Jaksa Agung, ${ }^{40}$ yang menandakan seseorang

${ }^{38}$ Chaerudin, Syaiful Ahmad, Syarif Fadillah, Strategi Pencegahan dan Penegakan Hukum Tindak Pidana Korupsi, (Bandung: Refika Adhitama, 2008), hlm. 123.

${ }^{39}$ Lebih lanjut lihat ketentuan Pasal 8 UU No. 16 Tahun 2004.

${ }^{40}$ Lebih lanjut lihat ketentuan Pasal 10 UU No. 16 Tahun 2004. 
baru dianggap sah dan memiliki kewenangan sebagai penuntut umum.

Selama ini, kewenangan penuntutan yang ada di institusi KPK tidak lain dan tidak bukan merupakan kewenangan yang dilakukan oleh jaksa yang ditugaskan atau di-BKO-kan (Bawah Kendali Operasi) oleh institusi Kejaksaan RI (ia diangkat, disumpah dan diberhentikan oleh Jaksa Agung) untuk melakukan penuntutan perkara-perkara korupsi di KPK. Sebagai institusi yang bertugas menyelenggarakan penyelidikan, penyidikan dan penuntutan kasuskasus korupsi maka KPK memiliki landasan yang kuat untuk melakukan penuntutan tindak pidana pencucian uang, selagi dan selama tindak pidana pencucian uang yang tindak pidana asalnya adalah tindak pidana korupsi.

Dalam kajian kewenangan maka pada proses penuntutan TPPU yang dilakukan oleh jaksa penuntut umum pada KPK, melekat kewenangan atribusi, karena jaksa penuntut umum pada KPK adalah jaksa yang dilantik, disumpah dan ditugaskan oleh institusi kejaksaan untuk melakukan penuntutan di KPK. Jika berkaca dari putusan pengadilan tipikor atas dakwaan jaksa penuntut umum pada KPK yang menggabungkan pidana asal berupa tindak pidana korupsi dengan TPPU atas beberapa terdakwa yang dinyatakan bersalah maka hal ini semakin mempertegas bahwa KPK memang mempunyai wewenang melakukan penuntutan terhadap tindak pidana pencucian uang yang tindak pidana asalnya adalah tindak pidana korupsi.

\section{Kesimpulan}

Pencegahan dan pemberantasan TPPU memerlukan landasan hukum yang kuat untuk menjamin kepastian hukum, efektifitas penegakan hukum, serta penelusuran dan pengembalian harta kekayaan hasil tindak pidana. Usaha untuk mewujudkan peraturan yang baik serta sesuai dengan kondisi maupun situasi tertentu, politik hukum pidana berusaha untuk membuat peraturan perundang-undangan pidana, yakni UU No 8 Tahun 2010 sebagai ius constitutum dalam pencegahan dan pemberantasan TPPU.

Kewenangan melakukan penuntutan pada perkara TPPU yang tindak pidana asalnya adalah tindak pidana korupsi menurut UU No. 8 Tahun 2010 dapat dilakukan oleh jaksa penuntut umum dari kejaksaan dan jaksa penuntut umum dari KPK apabila tindak pidana asalnya tindak pidana korupsi.Ketentuan Pasal 76 Ayat (1) UU TPPU harus dimaknai bahwa penuntut umum sebagai satu kesatuan, sehingga apakah penuntut umum yang bertugas di Kejaksaan Agung RI atau yang bertugas di KPK adalah sama. Dengan demikian, penuntut umum KPK berwenang melakukan penuntutan pada kasus TPPU yang tindak pidana asalnya adalah tindak pidana korupsi.

\section{Saran}

Untuk menghentikan perdebatan kewenangan KPK dalam melakukan penuntutan perkara TPPU sebagaimana diatur oleh UU No. 8 Tahun 2010 tentang TPPU maka perlu merevisi ketentuan Penjelasan Pasal 76 dengan menyebutkan bahwa penuntut umum di KPK mempunyai kewenangan melakukan penuntutan terhadapa tindak pidana pencucian uang jika tindak pidana asalnya adalah tindak pidana korupsi yang ditangani oleh KPK.

\section{Referensi}

Barda Nawawi Arief. 2001. Masalah Penegakan Hukum \& Kebijakan Penanggulangan Kejahatan. Bandung: Citra Aditya Bakti.

Bernard Arief Sidharta. 1999. Refleksi Tentang Struktur IImu Hukum: Sebuah Penelitian Tentang Fondasi Kefilsafatan dan Filsafat Keilmuan IImu Hukum 
Sebagai Landasan Pengembangan IImu Hukum Nasional Indonesia. Bandung: Mandar Maju.

Cainur Arrasjid. 2011. Hukum Pidana Perbankan. Jakarta: Sinar Grafika.

Chaerudin dkk. 2008. Strategi Pencegahan dan Penegakan Hukum Tindak Pidana Korupsi. Bandung: Refika Adhitama.

Donald R Cressey. 1969. The Theft of the Nation: The Strcture and Operation of Organized Crime in America. New York: Harper and Row.

Ermansyah Djaja. 2010. Meredesain Pengadilan Tindak Pidana Korupsi. Jakarta: Sinar Grafika.

Guy Stessens. 2000. Money Laundering : A New International Law Enforcement Model. Cambridge University Press: First Published.

Imam Syaukani dan A. Ahsin Thohari. 2007. Dasar-Dasar Politik Hukum. Jakarta: PT Raja Grafindo Persada.

Iwan Kurniawan. Perkembangan Tindak Pidana Pencucian Uang (Money Laundering) dan Dampaknya Terhadap Sektor Ekonomi dan Bisnis. Jurnal IImu Hukum. Volume 3. Nomor 1. 2010.

Romli Atmasasmita. 2010. Globalisasi dan Kejahatan Bisnis. Jakarta: Kencana.

Sabatini H. Implementasi Undang-Undang Tindak Pidana Pencucian Uang (TPPU) di Indonesia (Suatu Gambaran Tentang Pengetahuan dan Aplikasi Aparat Penyidik Penuntut Umum dan PPATK). Jurnal Kriminologi Indonesia. Volume 6. Nomor III. Desember 2010.

Sutan Remy Sjahdeini. 2004. Seluk-Beluk Tindak Pidana Pencucian Uang dan Pembiayaan Terorisme. Jakarta: PT Pustaka Utama Grafiti.

Teguh Sulistia dan Aria Zurnetti. 2011. Hukum Pidana Horizon Baru Pasca Reformasi. Jakarta: Raja Grafindo Persada.

Toetik Rahayuningsih. Analisis Peran PPATK Sebagai Salah Satu Lembaga Dalam Menanggulangi Money Laundering di Indonesia. Jurnal Yuridika. Volume 28. Nomor 3. September-Desember 2013.

Yahya Harahap. 2010. Pembahasan Permasalahan dan Penerapan KUHAP. Jakarta: Sinar Grafika.

Yunus Husein. PPATK: Tugas, Wewenang, dan Peranannya Dalam Memberantas Tindak Pidana Pencucian Uang. Jurnal Hukum Bisnis. Volume 22 Nomor 3. 2003. Tindak Pidana Pencucian Uang (Money Laundering) Dalam Perspektif Hukum Internasional. Jurnal Hukum International (Indonesian Journal of International Law). Volume 1. Nomor 2. 2014. 